\title{
Ayırıcı tanıda düşünülmesi gereken akut karın nedeni: primer peritonit
}

Zeliha AKIŞ YILDIZ ${ }^{1}$, Ceyhan ŞAHIIN ${ }^{1}$, Mehmet ARPACIK ${ }^{1}$ Aytekin KAYMAKÇI $^{2}$

\begin{tabular}{|c|c|}
\hline$\overline{\mathbf{O} z}$ & Yayın Bilgisi \\
\hline Calısmamızda karın ağrısı ile basvurup kısa sürede sistemik inflamatuar yanıt gelisen & Gönderi Tarihi:21.02.2018 \\
\hline çocuk hastanın tanı ve tedavisini sunduk. Aynı gün başlayan karın ağrısı nedeniyle & Kabul Tarihi:29.03.2018 \\
\hline $\begin{array}{l}\text { başvuran } 4 \text { yaşındaki kız olgunun batın muayenesi peritonit ile uyumlu idi. Akut faz } \\
\text { reaktanları yüksek olan hastanın görüntüleme tetkikleri normaldi. Kısa sürede genel }\end{array}$ & Online Yayın Tarihi:30. \\
\hline $\begin{array}{l}\text { reaktanları yüksek olan hastanın görüntüleme tetkikleri normaldi. Kisa sürede genel } \\
\text { durumu bozulan hastaya geniş spektrumlu antibiyotik ve antiviral tedavi başlandı. Cerrahi }\end{array}$ & DOI: $10.26453 /$ otjhs.397426 \\
\hline $\begin{array}{l}\text { ve medikal tedaviye yanıt veren hasta başvurudan } 2 \text { hafta sonra taburcu edildi. Akut karın } \\
\text { tablosu ile gelen her hastanın ayrıcı tanısında primer peritonitte düşünülmelidir. }\end{array}$ & $\begin{array}{r}\text { Sorumlu Yazar } \\
\text { Zeliha AKIS YILDIZ }\end{array}$ \\
\hline
\end{tabular}

\section{A cause of acute abdomen that must be taken into account in differential diagnosis:} primary peritonitis

Zeliha AKIŞ YILDIZ ${ }^{1}$, Ceyhan ŞAHIN ${ }^{1}$, Mehmet ARPACIK ${ }^{1}$ Aytekin KAYMAKÇI ${ }^{2}$

\begin{abstract}
In our study, we present the diagnosis and treatment of a child patient with abdominal pain, developing acute systemic inflammatory response.

A 4-year-old girl with abdominal pain starting on the same day was compatible with peritonitis in her abdominal examination. Imaging studies of patient were normal, acute phase reactants were high. In the short term, the general condition of the patient was deteriorated and wide spectrum antibiotics and antiviral treatment were started. The patient responded to surgical and medical treatment and was discharged 2 weeks after admission. Primer peritonitis should be considered in the differential diagnosis of each patient with an acute abdomen.
\end{abstract}

Article Info

Received:21.02.2018

Accepted:29.03.2018

Online Published:30.09.2018

DOI: $10.26453 /$ otjhs. 397426

Corresponding Author

Zeliha AKIŞ YILDIZ

Keywords: : Genitalia, 21-hydroxylase, congenital adrenal hyperplasia, baby

${ }^{1}$ Çocuk Cerrahisi: Sağlık bilimleri Üniversitesi Ümraniye Eğitim ve Araştırma Hastanesi, İSTANBUL/ TÜRKİYE

${ }^{2}$ Sağlık bilimleri Üniversitesi Ümraniye Eğitim ve Araştırma Hastanesi, İSTANBUL/TÜRKIYYE

\section{OLGU SUNUMU}

Daha öncesinde sağlıklı olan 4 yaşında kız hasta 4-5 saattir olan karın ağrısı, kusma ve ateş nedeniyle acil servise başvurdu. Üç gün önce kulak ağrısı nedeniyle gitmiş olduğu sağlık ocağında üst solunum yolu enfeksiyonu tanısıyla ağrı kesici başlanmış olduğu öğrenildi.

Hastanın başvuru anındaki fizik muayenesinde, uykuya meyilli, soluk ve dehidrate görünümde idi. Kalp tepe atımı 140/dk, tansiyon 90/60 mm Hg, akciğer sesleri ise normaldi. Batında yaygın hassasiyet ve defans mevcuttu. Hasta acil serviste monitorize edildi, idrar sondası ve nazogastrik sonda takıldı. Hemoglobin: $10,7 \mathrm{~g} / \mathrm{dL}$, hemotokrit: \%34, kan biyokimyasında elektrolit ve karaciğer enzimleri normal, üre:49,2 $\mathrm{mg} / \mathrm{dL}$ kreatinin:0,53 mg/dL idi. Tam idrar tetkiki normal olarak bulundu.

Akciğer ve batın grafileri normal olarak değerlendirildi. Batın ultrasonografisi ve 
tomografisinde patoloji saptanmadi. Hastanın 4 saat sonra genel durumu bozulmaya başladı. Oksijen saturasyonu \%90'ın ve idrar çıkışı $\mathrm{kg}$ başına 0,5 mL'nin altında olması üzerine yoğun bakıma yatırıldı.

Yoğun bakımda maske ile oksijen verilen hastadan alınan kontrol kanlarında C reaktif protein (CRP): 11,5 $\mathrm{mg} / \mathrm{dL}$, procalsitonin $>100 \mathrm{ng} / \mathrm{mL}$ olarak saptand . Takipneik, taşikardik, periferik dolaşımı bozuk ve oligürisi olan hasta SIRS (Sistemik İnflamatuar Response Sendromu) olarak değerlendirildi. Kan ve idrar kültürleri alındı. Ampirik olarak Meropenem+vankomisin+oseltamivir başland1.

\section{Bu hastada olası tanını nedir?}

Acil serviste çocuk cerrahisi tarafinda değerlendirilen hastaya primer peritonit tanıs1 konuldu. Öncelikle tedavisinde cerrahi girişim düşünülmeyen hastanın yoğun bakımda 2. gününde genel durumunun kötü, bilincinin letarjik, batında distansiyon, CRP (20 mg/dL) ve prokalsitonin ( $100 \mathrm{ng} / \mathrm{mL}$ ) artışı olması üzerine tanısal laparaskopi yapıldı. Batında seropürülan mayi ve fibrin saptandı. Batındaki sıvıdan kültür alındı daha sonra batın yıkandı ve batına diren yerleştirilerek operasyon sonlandırıldı. Hastanın tbc ve kollojen doku hastalığı yönünden ayrıca BOS ta micobakteri ve herpes açısından tetkikleri istendi. Paranteral beslenme ve intravenöz immünglobulin (IVIG) başlandı, plazmaferez yapıldı. Postoperatif 4. günden sonra genel durumunda düzelme gözlenen hastanın CRP: $10.4 \mathrm{mg} / \mathrm{dL}$, procalsitonin: $\quad 61.3 \mathrm{ng} / \mathrm{mL}$, üre: 29.9 mg/dL, kreatinin: $0.46 \mathrm{mg} / \mathrm{dL}$ ve INR: 1.29 olarak saptandi. Kan kültüründe Streptococus pyogenes üreyen, assit kültüründe üreme olmayan hasta oseltamivir tedavisi 7 güne, meropenem ve vankomisin tedavisi 14 güne tamamlanarak şifa ile taburcu edildi.

\section{TARTIŞMA}

Primer peritonit, herhangi bir intraabdominal kaynak olmadan peritonun enfeksiyonudur. $^{1,2}$ Çocukluk çağı akut batınların \%1 ini oluşturur ve ameliyat öncesi çok ender tanı alır., ${ }^{3,4}$ Primer peritonitin mekanizması tam olarak anlaşılmamakla birlikte enfeksiyonun genellikle hematojen yolla, solunum sisteminden, lenfatik sistemden, sağlam barsak duvarından transmural migrasyon ile yada kadınlarda genital yol ile ulaştığı düşünülmektedir. ${ }^{5}$ Genellikle immün yetmezliği, siroz ve nefrotik sendrom gibi sağlık sorunları olan çocuklarda görülür 
ancak ender olarak bizim olgumuzda olduğu gibi sağlıklı çocuklarda da görülebilmektedir. ${ }^{6,7,8} \quad$ Antibiyotik kullanımı ile birlikte 1950 lerden sonra görülme sıklığ1 \%10'dan \%1'e düşmüştür. ${ }^{4}$

Primer peritonitli hastalar çoğunlukla karın ağrısı, kusma ve ateş ile başvururlar. Muayenede olgumuzda olduğu gibi batında hassasiyet ve defans çoğunlukla mevcuttur. ${ }^{4}$ Assit sıvı kültüründe genellikle Streptococus pneumonia, Streptococus pyogenes, Escherichia coli, Klebsiella pneumonia, bazende Neisseria gonorrhoeae, Chlamydia trachomatis, Mycobacterium tuberculosis ürer. Olgumuzda olduğu gibi assit sıvısında üreme olmaması ise çok enderdir. ${ }^{4,9}$

Tanı hikaye, fizik muayene ve labaratuar sonuçları ile konur. Primer peritonitli olgularda apandisit, divertikülit, peptik ülser perforasyonu gibi akut batın nedenleri ekarte edilmelidir. Çoğu zaman tanı koymak oldukça zordur ve genellikle sekonder peritonit düşünülerek yapılan laparotomide tanı konur. ${ }^{10-12}$ Ancak primer peritonitten şüphelenilirse peritoneal aspirat ile tanı konulabilir. ${ }^{13}$ Assit sıvında $\mathrm{pH} \leqslant 7.34$, laktat $>2.8 \mathrm{mmol} / \mathrm{L}$, PMNL $>500 / \mathrm{mm}^{3}$ olması ve assit kültüründe etyolojik ajanın üretilmesi tanıda yardımcıdır. ${ }^{4,14}$
Tedavide geniş spektrumlu antibiyotikler ampirik olarak başlanmalı ve sonrasında kültür sonuçlarına göre değiştirilmelidir. ${ }^{4}$ Assit sıvısındaki bakteriyel yükü azaltmak için peritoneal lavaj yapılabilir. ${ }^{15}$ Laparoskopi primer peritonit düşünülen olgularda güvenli bir yöntem olarak

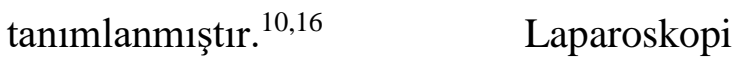
laparotomiye göre daha güvenlidir ancak debridman daha zordur. ${ }^{4}$ Olgumuzda da primer peritonit tanısı konularak geniş spektrumlu antibiyotikler ampirik olarak başlanmıştır. Genel durumunun giderek bozulması nedeniyle laparoskopi yapılarak hem sekonder peritonit nedenlerini ekarte edilmiş hem de bakteriyel yük azaltılmıştır. Bazı yazarlar apendektomiyi önerirken diğerleri sağlıklı bir organı almayı uygun bulmamaktadır. $^{5}$ Bizim olgumuzda apendektomi yapılmamıştır.

Karın ağrısı ile gelen olgularda primer peritonit tanısı da akılda tutulmalıdır. Şüphenilen olgularda tanısal laparaskopi yapılması ve ampirik antibiyotik başlanmasının hayat kurtarıcı olabileceği kanaatindeyiz.

\section{KAYNAKLAR}

1. Wilcox CM, Dismukes WE. Spontaneous bacterial peritonitis. A review of pathogenesis, diagnosis, and 
treatment. Medicine (Baltimore). 1987;66(6):447-456

2. M.E. Levinson, L.M. Bush, Peritonitis and other intra-abdominal infections, in: G.L. Mandell, J.E. Bennett, R. Dolin (Eds.), Principles and Practice of Infectious Diseases, Churchill Livingstone, Elsevier, Philadelphia. 2005; 927-951.

3. Fowler R. Primary peritonitis: changing aspects 1956-1970. Aust Paediatr J. 1971; 7(2): 73-83

4. Muhammad Faisal Khilji. Primary Peritonitis-A Forgotten Entity. Eur J Pediatr Surg Rep. 2015; 3: 27-29.

5. West KW. Primary peritonitis. In: O’Neill JA, Roe MI, Grosfeld JL, eds. Pediatric Surgery, 5th ed. St. Louis, MO: Mosby; 1988: 1345-1348.

6. Larcher VF, Manolaki N, Vegnente A, Vergani D, Mowat AP. Spontaneous bacterial peritonitis in children with chronic liver disease: clinical features and etiologic factors. J Pediatr. 1985; 106(6): 907-912

7. Gorensek MJ, Lebel MH, Nelson JD. Peritonitis in children with nephrotic syndrome. Pediatrics. 1988;81(6):849856

8. McDougal WS, Izant RJ Jr, Zollinger RM Jr. Primary peritonitis in infancy and childhood. Ann Surg. 1975; 181(3): 310-313.
9. Sheckman P, Onderdonk AB, Bartlett JG. Anaerobes in spontaneous peritonitis. [letter]Lancet. 1977; 2(8050): 1223

10. Kimber CP, Hutson JM. Primary peritonitis in children. ANZ J Surg. 1996; 66: 169-170.

11. Blevrakisa E, Anyfantakis D, Blevrakisc E, Vlachakis I. Primary bacterial peritonitis in a previously healthy adolescent female: A case report. International Journal of Surgery Case Reports. 2016; 28: 111-113.

12. Mark Malotaa, Thomas W. Felbingerb, Reinhard Rupperta, Natascha C. Nüsslera Group A Streptococci: A rare and often misdiagnosed cause of spontaneous bacterial peritonitis in adults. International Journal of Surgery Case Reports. 2015; 6: 251-255.

13. Westwood DA, RobertsRH, Management of primary group. Astreptococcal peritonitis: asystematic review. Surg Infect(Larchmt). 2013; 14(2): 171-176.

14. Alaniz C, Regal RE. Spontaneous Bacterial Peritonitis : a review of treatment options. P T. 2009; 34(4): 204-210.

15. Strauss RM, Dienstag JL. Ascites and its complications. In: Morris PJ, Malt RA eds. Oxford Textbook of Surgery. 
New York, NY: Oxford University Press; 1994: 1265-1271.

16. Block SL, Adams G, AndersonM.

Primary pneumococcal peritonitis

. J Pediatr Surg. 1998; 33(9): 1416-1417. complicated by exudative pleural effusion in an adolescent girl 